Aquaculture

September 2019, Volume 511, Pages 734242 (10p.)

https://doi.org/10.1016/i.aquaculture.2019.734242

https://archimer.ifremer.fr/doc/00503/61490/

\title{
Gill transcriptomic analysis in fast- and slow-growing individuals of Mytilus galloprovincialis
}

\author{
Prieto Daniel 1, ", Markaide Pablo ${ }^{1}$, Urrutxurtu Iñaki ${ }^{1}$, Navarro Enrique ${ }^{1}$, Artigaud Sebastien ${ }^{2}$, \\ Fleury Elodie ${ }^{3}$, Ibarrola Irrintzi ${ }^{1}$, Urrutia Miren Bego ${ }^{1}$
}

1 GIU 17/061, GI 544, Departamento de Genética, Antropología Física y Fisiología Animal, Facultad de Ciencia y Tecnología, Universidad del País Vasco/Euskal Herriko Unibertsitatea, UPV/EHU, Apartado 644, 48080 Bilbao, Spain

2 LEMAR UMR 6539 CNRS/UBO/IRD/Ifremer, IUEM, rue Dumont d'Urville, 29280 Plouzané, France

${ }^{3}$ LEMAR, UMR 6539 UBO-CNRS-Ifremer-IRD, Technopole Brest Iroise 29280 Plouzané, France

*Corresponding author : Daniel Prieto, email address : dani.prieto.perez@hotmail.com

\begin{abstract}
:
The molecular basis underlying the mechanisms at the origin of growth variation in bivalves is still poorly understood, although several genes have been described as upregulated in fast-growing individuals. In the present study, we reared mussel spat of the species Mytilus galloprovincialis under diets below the pseudofaeces threshold (BP) and above the pseudofaeces threshold (AP). After 3 months, $F$ and $S$ mussels from each condition were selected to obtain 4 experimental groups: FBP, SBP, FAP and SAP. We hypothesized that the nurturing conditions during the growing period would modify the molecular basis of their growth rate differences.
\end{abstract}

To decipher the molecular mechanisms underlying the growth variation, the gill transcriptomes for the four mussel groups were analysed. Gene expression analysis revealed i) a low number (12) of genes differentially expressed in association with diet and ii) 117 genes differentially expressed by the fast- and slow-growing mussels. According to Biological Process GO term analysis transcriptomic differences between the $\mathrm{F}$ and $\mathrm{S}$ mussels were mainly based on the upregulation of: response to the stimulus, growth and cell activity. Regarding the KEGG terms, carbohydrate metabolism and the Krebs cycle were upregulated in $\mathrm{F}$ mussels, whereas biosynthetic processes were upregulated in $\mathrm{S}$ mussels. In accordance with their larger gill surface area and higher rates of feeding and growth, the $\mathrm{F}$ individuals overexpressed genes in their gill tissues, and these were involved in i) growth (insulin-like growth factors and myostatin); ii) maintenance of the structure and functioning of extracellular matrix (collagen, laminin, fibulin and decorin); iii) filtration and ciliary activity (mucin, fibrocystin, dynein and tilB homolog protein genes); iv) aerobic metabolism (citrate synthase and carbonic anhydrase); and v) the immune-system, probably in association with haemocytes. In contrast, $S$ individuals overexpressed a different series of genes pertaining to immune system (leucine-rich repeat protein and galectin), along with genes involved in the response to cellular stress (Heat shock protein (HSP24) and metalloendopeptidase) as well as anaerobic metabolism (C4-dicarboxylate transporter). These results might suggest that $\mathrm{S}$ individuals would have a greater prevalence of pathogens/diseases or a higher susceptibility to the pathogens. 


\section{Highlights}

- Fast- and slow-growing mussel (Mytilus galloprovincialis) spat were found to differentially express 117 genes in gill tissue. - Fast-growing mussels overexpressed genes involved in response to stimulus,growth and cell activity processes. Slow-growing mussels overexpressed genes involved in immune and defence processes. Feeding above or below the pseudofaeces production threshold did not exert a relevant effect on the gill transcriptome.

Keywords : Fast-growing, mussel, gill, transcriptome 


\section{Introduction}

Both endogenous factors and environmental conditions influence the growth rate in bivalves (Brown, 1988; Dickie et al. 1984; Mallet and Haley, 1983; Pace et al. 2006; Tamayo et al. 2011). Studies comparing the physiological behaviour between fast- and slow-growing individuals have greatly contributed, in the last two decades, to the understanding of the physiological basis of differential growth. The main conclusions were that differences in growth rates resulted from differences in i) the capacity to acquire and absorb food, ii) the efficiency of energy conversion processes and/or iii) the allocation of energy to growth and maintenance (Koehn and Shumway, 1982; Toro and Vergara, 1998; Bayne et al. 1999a, 1999b; Tamayo et al. 2014; Fernández-Reiriz et al. 2016).

The multilocus heterozygosity hypothesis formulated by Sighn and Zouros (1978) established the existence of a positive correlation between the degrees of heterozygosity and growth rate. Aneuploidy was also demonstrated to play a role in interindividual differences in growth rate in bivalves: significantly higher values of aneuploidy of gill cells were observed in slow-growing specimens of oysters (Crassostrea gigas) and more recently in the clam Ruditapes decussatus, with a high negative correlation observed between growth rate and aneuploidy percentage (Leitao et al. 2001; Teixeira De Sousa et al. 2011). 
In recent years, high throughput gene expression analyses have used nextgeneration sequencing (NGS) or microarrays, with the aim of deciphering the underlying mechanisms, and these techniques have allowed the identification of genes involved in growth processes (Gracey et al. 2008; Lockwood et al. 2010; Sus sarellu et al. 2010; Devos et al. 2015; Suarez-Ulloa et al. 2015; Xu et al. 2016). For instance, Zhang et al. (2012) reported that collagen and laminins, (extracellular matrix proteins from connective tissue) and fibronectins are involved in the formation of the shell in the oyster Crassostrea gigas. Bassim et al. (2014) analysed the gene expression of the mussel Mytilus edulis during early development (from egg to post-larvae), identified a set of genes related to growth processes in early development (e.g., GATAD1, PIP5K1A and ATRX) and highlighted (Bassim et al. 2015) 29 gene markers related to growth and mortality of bivalve larvae.

Very few studies have attempted to specifically analyse the differential gene expression between fast- and slow-growing specimens of bivalves. Using different crosses between inbred lines of Crassostrea gigas, Meyer and Manahan (2010) found significant differences between fast- and slow-growing larval families in the transcript abundance of ribosomal proteins as well as in the rates of expression of genes encoding for the small cardioactive peptide precursor ( $\mathrm{ScPB}$ ), which is involved in feeding regulation and in several proteins involved in the energy metabolism. Some of them were electron transport components encoding genes (ND4L and ND1), ATP-synthase 8, and two coiled-coil-helix-coiled-coil-helix domains (CHCHD2 and CHCHD). More recently, De la Peña et al. (2016) reported the existence of significant differences in the rate of expression of ferritins (Apferl) between fast- and slow-growing individuals of Argopecten purpuratus at different developmental stages (5 stages from embryos to juveniles). Wilson et al. (2016) produced an inbred fast growth line (F) of Mya arenaria clams and analysed the gene expression to test the hypothesis that specific growthrelated genes will be upregulated in $\mathrm{F}$ individuals. These authors established a positive correlation between some metabolic genes (fatty acid synthase and ATPase) with fast growth. These authors also found some upregulated genes involved in structural remodelling in a fast-growing phenotype in agreement with previous studies indicating protein turnover as the main determinant processes for growth heterosis. Finally, Saavedra et al. (2017) concluded that a set of genes controlling tissue and organ growth processes in model organisms (named 'GCGC') displayed a minor role in determining $\mathrm{F}$ 
and $\mathrm{S}$ in Ruditapes decussatus stocks. However, they found that the insulin-mediated processes had an essential role in interindividual differences in growth rate.

Although the available genetic information is increasing (Saavedra and Bachere, 2006; Tanguy et al. 2008; Astorga et al. 2014)-e.g., the genome of the oyster Crassostrea gigas was published in 2012 (Zhang et al. 2012) — knowledge regarding molecular and genetic interindividual differences in the growth potential of bivalves remains at low standards. Large-scale sequencing projects (e.g., NGS) have produced large amounts of sequences in databases, but a significant part of these sequences lack an assigned function or similarity. Therefore, a combination of analyses of the transcriptome and other organizational level responses is necessary to understand the roles of specific genes in the functional responses at the level of the whole organism (Bassim et al. 2014).

In the present study, we have analysed the gene expression in gill tissue of mussel (Mytilus galloprovincialis) specimens that were selected as fast (F) and slow (S) growers after rearing them for three months in the laboratory under two different nutritional environments. After the rearing period, the physiological components of the Scope for Growth of the selected $\mathrm{F}$ and $\mathrm{S}$ mussels were recorded under different experimental diets to assess the influence of rearing conditions on the parameters of the physiological behaviours responsible for faster growth (Prieto et al., in preparation). Irrespective of feeding conditions during rearing, faster growers exhibited higher Scope for Growth values that mainly resulted from their increased capacity to acquire food. Indeed, fast growers displayed higher clearance rates, and they consistently were found to have significantly higher gill-surface area per mass unit than their slow-growing counterparts. The combination of higher gill-surface area with higher clearance rate in fast-growing individuals is a phenotypical feature that we have also observed in previous studies performed with mussels (Prieto et al. 2018) and clams (Tamayo et al. 2011).

Thus, the gill is one of the organs likely playing a major role in determining the interindividual growth rate differences in the mussel Mytilus galloprovincialis. Accordingly, in the present study, we have selected the gill tissue as the target organ to compare gene expression in these groups of fast and slow-growing mussels. The aims of this study were to search for candidate genes for recorded differences in physiological behaviour and, ultimately, in growth, to ascertain biological processes accounting for 
such differences at the molecular level. Additionally, the effect of the rearing nutritional condition was also considered as a possible modulator of molecular processes underlying the interindividual differences in growth rate. Specifically, emphasis was placed on linking physiological (Prieto et al., in preparation) and transcriptomic results (present study) to achieve a more holistic understanding of the organism behaviour in different growth scenarios.

\section{Material and Methods}

\subsection{Selection of mussels}

Some 400 mussels (Mytilus galloprovincialis) of approximately $10 \mathrm{~mm}$ shell length ( 150 mg live weight) were collected in a rocky shore in Antzoras (Bizcay, North Spain) in February 2014. Once at the lab, we reared each half of the mussels at one of the two "maintenance conditions" (named AP and BP) designed to force different feeding strategies in both groups: a group of 200 mussels was fed a highquality diet (organic content $=80 \%$ ) dosed at a particle volume concentration of 1.0-1.5 $\mathrm{mm}^{3} / \mathrm{L}$ (below the pseudofaeces threshold; maintenance condition BP), and the other group of 200 mussels was fed a low-quality diet (organic content $=30 \%$ ) dosed at particle volume concentration of $3.0-3.5 \mathrm{~mm}^{3} / \mathrm{L}$ (above the pseudofaeces threshold: maintenance condition AP). Diets were a mixture of cultured Isochrysis galbana (Tiso), lyophilized Phaeodactylum tricornutum and freshly collected and sieved particles of natural sediment.

Shell length was measured with a 0.05 accuracy calliper, and live-weight was determined using a $0.01 \mathrm{mg}$ accuracy balance. After three months, the largest and smallest 24 individuals, representing the percentiles $\mathrm{P}_{12.5}$ and $\mathrm{P}_{87.5}$ in size distribution of each group, were selected as fast (F) and slow (S) growers respectively. Accordingly, four experimental groups of mussels were obtained combining maintenance (BP and AP) and growth (F or S) conditions: i) fast-growing mussels fed below the pseudofaeces threshold $\left(\mathrm{F}_{\mathrm{BP}}\right)$, ii) slow-growing mussels fed below the pseudofaeces threshold $\left(\mathrm{S}_{\mathrm{BP}}\right)$, iii) fast-growing mussels fed above the pseudofaeces threshold $\left(\mathrm{F}_{\mathrm{AP}}\right)$, and iv) slowgrowing mussels fed above the pseudofaeces threshold $\left(\mathrm{S}_{\mathrm{AP}}\right)$. The growth rates of the mussels were calculated as GR = the increase in the shell-length or live-weight/elapsed time (days). After the physiological experiments had been completed, the gills of the 
mussels were dissected and processed for gill surface area determination and RNA extraction.

\subsection{RNA extraction}

Gill samples were stored immersed in RNAlater at $-80{ }^{\circ} \mathrm{C}$ until the RNA from the gill of 20 mussels coming from each one of the four experimental groups $\left(\mathrm{F}_{\mathrm{BP}}, \mathrm{S}_{\mathrm{BP}}\right.$, $\mathrm{F}_{\mathrm{AP}}$ and $\mathrm{S}_{\mathrm{AP}}$ ) were individually extracted with a 'RiboPure RNA Purification Kit' (Ambion kit). The analysis of the quality and integrity of the RNA was checked with Fragment Analyzer ${ }^{T M}$ Automated CE System equipment from Advanced Analytical with 'DNF-471 Standard Sensitivity RNA Analysis kit', (15 nt) and Fragment Analyzer $^{\mathrm{TM}}$ 1.1.0.11 software. The RNA quality was checked using PROSize 2.0 and the RNA concentration was measured in the spectrophotometer UV/VIS Nanodrop 1000 (Thermo Fisher).

Each individual RNA sample was then diluted to a common concentration of $100 \mathrm{ng} / \mathrm{ul}$. After that, the 20 individual RNA samples per experimental group were randomly combined to create 4 different pools composed of 5 individuals. To create the pools, the same RNA quantity (500 ng) from each of the 5 individuals was added. Once created, the concentration of the pools was quantified in the Nanodrop 1000. Thus, we obtained 16 different pools (4 pools from each experimental group x 4 experimental groups), each one containing RNA from 5 different individuals. After that, the 16 pools were marked as described in the section 2.3.1.

\subsection{Microarray design and hybridization}

We used a SurePrint G3 Custom microarray (8x60 k) from Agilent to analyse the transcriptome of the gill samples. Microarray probes were designed using Agilent eArray platform, using Mytilus galloprovincialis sequences downloaded from NCBI in February of 2015. Sequences with the best Blastx hit (e-value $<10 \mathrm{e}^{-10}$ ) to unique proteins against nonredundant database were selected. Three nonidentical probes were designed for each sequence. Housekeeping genes (those usually used in Mytilus qPCR analysis) were added as positive controls, alongside default Agilent negative controls. The remaining spots in the array were filled with sequences of the genus Mytilus representing unique proteins (were Mytilus galloprovincialis orthologue was missing). Two probes of the unannotated sequence (one in each reading direction) were included in the array. Thus, the array was based on 17,491 unannotated and 7,806 annotated 
sequences. The platform is available in gene expression omnibus (GEO) repository with the accession number GPL25650. Hybridization was performed in 16 pools (4 different pools of different 5 individuals per experimental group). Pools were randomly hybridized in the arrays, including at least one pool per experimental group in each array.

\subsubsection{Marking protocol}

We used the 'One-Color Microarray-Based Exon Analysis' marking protocol from Agilent. Samples were marked using 'Low Input Quick Amp WT Labeling kit, One-Color' (p/n 5190-2943) kit. In total, 100 ng of RNA was used for the marking reaction. Marked samples were quantified with a Nanodrop ND-1000 to determine the efficiency of the specific activity of the fluorochromes.

\subsubsection{Hybridization}

Samples were manually hybridized with SureHyb Hybridization Chambers (Agilent technologies). Hybridization was conducted in the oven of Agilent Technologies according to the Agilent protocol. The characteristics were as follows: 600 ng of marked cRNA, $40 \mu$ volume, $65^{\circ} \mathrm{C}$ temperature, and 20 hours duration at $10 \mathrm{rpm}$ in the hybridization.

\subsubsection{Scanning}

The scanning was carried out on the DNA Microarrays G2565CA scanner with ozone-barrier slide covers with the Scan Control Software version 8.5.1., using the default protocol AgilentG3_GX_1Color. The Scanning resolution was $3 \mu \mathrm{m}$, the green channel was used, and the size of the resulting Tiff image was 20 bits.

\subsubsection{Feature extraction}

We used Agilent Feature Extraction Software (ver. 10.7.3.1) (Agilent Technologies) to process the microarray images and to quantify the fluorescence of the probes. The quality of all arrays was evaluated using the $9 \mathrm{QC}$-metric parameters generated in the feature extraction. Following this procedure, the processed fluorescence signal (generated by the feature extraction) was obtained. 


\subsection{Data treatment}

Data treatment was carried out in $\mathrm{R}$ (v. 3.3.2.) using the limma package (v. 3.30.13) from Bioconductor (Ritchie et al. 2015). Probes were prefiltered using gIsPosAndSignif tag; a Boolean value indicating if the signal of the probe exceeds the background signal. Probes with a nonsignificant signal in all the samples of at least one experimental group $(\mathrm{n}=4)$ were removed. Background was corrected using normexp method, and normalization between the arrays was performed using the quantile method, as described in Smyth et al. (2002). Fold-change and standard error were estimated by fitting the data to a linear model and an empirical Bayes (eBayes) smoothing was applied to the standard errors. The final gene expression value was the average of the nonidentical probes corresponding to each sequence. Differential expression quantification was based on a logarithmic scale $(\operatorname{logFC})$, the adjusted pvalue or False Discovery rate (Benjamin-Hochberg method) representing the statistical significance of the observed changes. Probes with FDR $<0.05$ were considered differentially expressed, as suggested in Cheng and Pounds (2007). Hierarchical clustering (HCL) analysis was performed using dendextend package (v.1.5.2.) to analyse similarity between samples.

Normalized hybridization values, as well as the raw data, were deposited in the gene expression omnibus (GEO) repository with the accession number GSE120975.

\subsection{Annotation and gene ontology}

Microarray sequences were annotated using Annocript 1.3. against Swiss-Prot and UniRef databases (v. march-2017). Gene Ontology (GO) for three domains (Cellular Component, Molecular Function and Biological Process) was analysed for transcriptome data interpretation, although we focused our analysis mainly on the Biological Process (Suarez-Ulloa et al. 2015). The GO terms list was summarized using REVIGO (Supek et al. 2011). Differentially expressed genes were also mapped to the Kyoto Encyclopaedia of Genes and Genomes (KEGG) database for pathway analysis (Kanehisa, 2002). Conserved protein domains were identified using PROSITE (Sigrist et al. 2009) and NCBI conserved protein domain finder tools. 


\section{Results}

\subsection{Growth rates of the experimental mussel groups}

After 3 months of maintenance of the mussels under BP or AP conditions, the live weight of $\mathrm{F}$ individuals was 2.5 -fold higher than that of $\mathrm{S}$ individuals, and the shell length was $45 \%$ longer. Accordingly, live-weight and shell-length growth rates of $\mathrm{F}$ individuals was found to be approximately 3 times greater than that of $S$ individuals in both maintenance conditions (Table 1).

Table 1. Shell-length $(\mathrm{mm})$, live-weight $(\mathrm{g})$, shell-length growth rate $(\mathrm{mm} /$ day) and live-weight growth rate (g/day) (mean values $\pm \mathrm{SD}$ ) of $\mathrm{F}_{\mathrm{BP}}, \mathrm{S}_{\mathrm{BP}}, \mathrm{F}_{\mathrm{AP}}$ and $\mathrm{S}_{\mathrm{AP}}$ mussel groups. Number of individuals per mussel group $=24$

\begin{tabular}{ccccccc}
$\begin{array}{c}\text { Mussel } \\
\text { group }\end{array}$ & Length $(\mathrm{mm})$ & Live weight $(\mathrm{g})$ & $\begin{array}{c}\text { Growth rate } \\
(\mathrm{mm} / \text { day })\end{array}$ & $\begin{array}{c}\text { Growth rate } \\
(\mathrm{g} / \text { day })\end{array}$ \\
\hline $\mathrm{F}_{\mathrm{BP}}$ & $21.2 \pm 0.7$ & $0.9 \pm 0.1$ & $0.146 \pm 0.009$ & $0.012 \pm 0.002$ \\
$\mathrm{~S}_{\mathrm{BP}}$ & $13.9 \pm 1.2$ & $0.3 \pm 0.1$ & $0.055 \pm 0.015$ & $0.004 \pm 0.001$ \\
$\mathrm{~F}_{\mathrm{AP}}$ & $21.9 \pm 0.6$ & $1.0 \pm 0.1$ & $0.144 \pm 0.007$ & $0.011 \pm 0.001$ \\
$\mathrm{~S}_{\mathrm{AP}}$ & $15.4 \pm 1.0$ & $0.5 \pm 0.1$ & $0.060 \pm 0.013$ & $0.004 \pm 0.001$ \\
\hline
\end{tabular}

\subsection{Quality and reproducibility of the DNA microarray data}

The marked RNA quality was good in all samples. The yield and the Cyanine 3 specific activity were higher than $0.825 \mu \mathrm{g} /$ reaction and $15 \mathrm{pmol} / \mu \mathrm{g}$, respectively, in all marked samples. In all cases, the hybridization with the array suited (or passed) the quality standards, evaluated with 9 QC metrics parameters. Only in $0.95 \%$ of the probes (568 probes out of 59,539) did the signal have a lower expression value than the background on all samples. For our analysis, we used the probes that had a positive signal on all the samples in at least one experimental group. Mean expression values and standard deviations of the housekeeping genes of the array are shown in the additional file 1 . The variability among samples was lower than $3 \%$ in 19 of 20 housekeeping genes.

\subsection{Transcript annotation}

The functional annotation of the genes on the array carried out by Blastx against Swiss-Prot and UniRef databases had 38.8\% significant matches (E-value 10 ${ }^{-5}$ ): 10,001 out of 25,781 genes. In total, $27.7 \%$ of the annotated genes were matched on 
Crassostrea gigas, $10.2 \%$ on Homo sapiens, $8.4 \%$ on Mus musculus, and $3.6 \%$ on Lottia gigantea. A total of $3.5 \%$ of the matches were found on distinct species of the genus Mytilus (M. galloprovincialis 1.8\%, M. coruscus $0.5 \%$, M. trossulus $0.5 \%$, M. edulis $0.3 \%$ and $M . \operatorname{tax} 0.4 \%$ ). In addition, 15,333 (3,142 unique) GO terms were assigned to the annotated genes: 4,970 (32.4\%) were Biological Process terms; 4,335 (28.3\%) were Molecular function terms; and 6,091 (39.3\%) were Cellular Component terms. The KEGG ontology had 1,526 (378 Unique) matches.

\subsection{Sample distribution}

We performed a hierarchical clustering (HCL) with the whole transcriptomic data to analyse the similarity in the gene expression pattern between all samples. Two clusters were obtained on the HCL analysis of the transcriptome (Figure 1). The first cluster included mostly slow-growing mussels: 6 out of $8 \mathrm{~S}$ mussel pools were grouped in this cluster, whereas most of the F mussel pools ( 7 out of 8), were grouped in the second cluster. No clear differentiation pattern was found according to the maintenance $\operatorname{diet}(\mathrm{BP}$ vs AP).

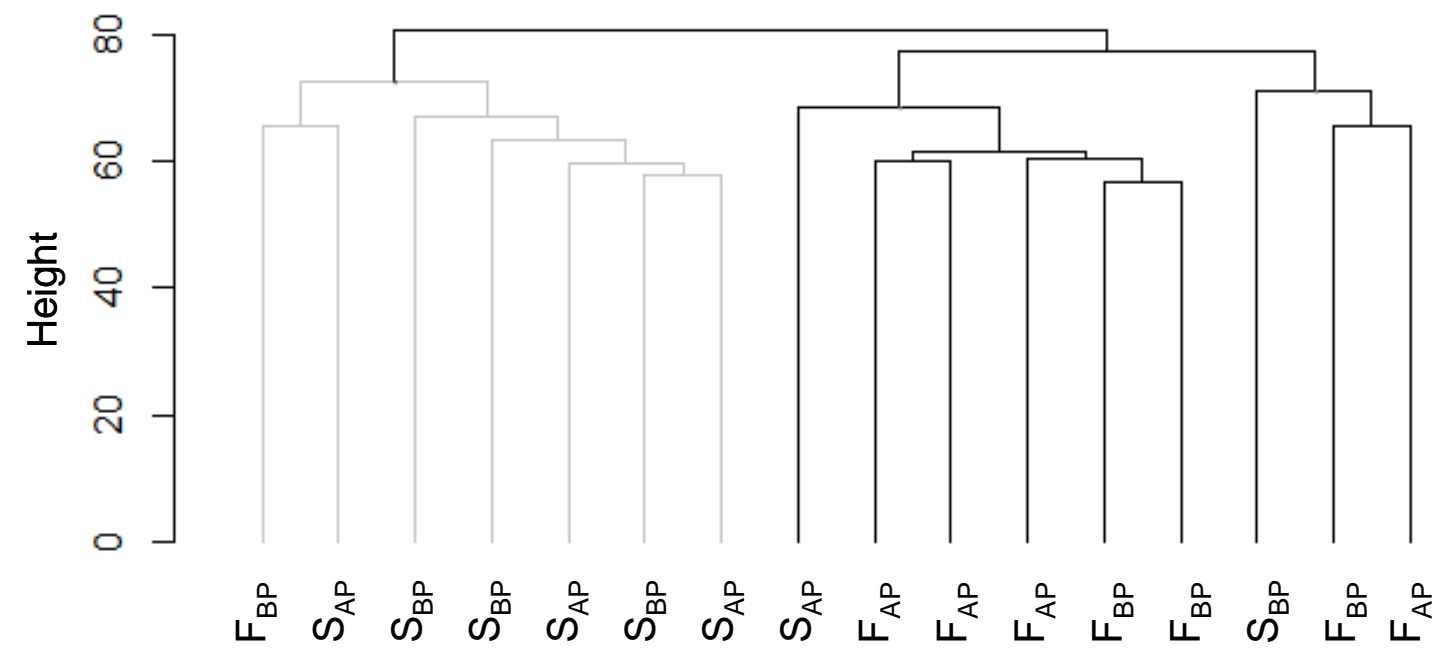

Figure 1. Hierarchical clustering (HCL) of gene expression of fast-growing $(\mathrm{F})$ and slow-growing (S) mussels of BP (Below Pseudofaeces threshold) and AP (Above Pseudofaeces threshold) conditions. The two main clusters obtained by the HCL are marked in grey and black.

\section{$\underline{\text { 3.5.Identification of differentially expressed genes }}$}

We performed 6 comparisons (FDR 5\%) to analyse the effect of growth condition and maintenance condition on the transcriptome of gill tissue (Table 2). 
Table 2. Number and fraction (DEG/total genes in the microarray) of differentially expressed genes (adj. $\mathrm{p}$ value $<0.05$ ) for the 6 comparisons between the experimental groups used to test the molecular effect of growth condition (fast or slow grower) and maintenance condition (reared in BP or AP conditions) factors.

\begin{tabular}{|c|c|c|c|c|}
\hline Tested factor & $\begin{array}{c}\text { Group } \\
\text { Comparis on }\end{array}$ & Upregulated & Downregulated & Fraction \\
\hline \multirow[t]{3}{*}{ Growth condition } & $\mathrm{F}_{\mathrm{BP}}$ vs $\mathrm{S}_{\mathrm{BP}}$ & 5 & 2 & 0.03 \\
\hline & $\mathrm{F}_{\mathrm{AP}} \mathrm{vs} \mathrm{S}_{\mathrm{AP}}$ & 1 & 0 & 0.00 \\
\hline & F vs $S$ & 70 & 47 & 0.51 \\
\hline \multirow[t]{3}{*}{$\begin{array}{c}\text { Maintenance } \\
\text { condition }\end{array}$} & $\mathrm{F}_{\mathrm{BP}} \mathrm{vs} \mathrm{F}_{\mathrm{AP}}$ & 1 & & 0.01 \\
\hline & $\mathrm{S}_{\mathrm{BP}}$ vs $\mathrm{S}_{\mathrm{AP}}$ & 2 & & 0.01 \\
\hline & BP vs AP & 7 & 5 & 0.05 \\
\hline
\end{tabular}

No strong effect of diet quality on the transcriptome profile was found since BP vs AP differences amounted to only $0.05 \%$ (12 genes: 7 upregulated and 5 downregulated). Effects were still less important when these quality differences were analysed by growth categories $(0.01 \%)$. Regarding the growth condition factor, 117 genes $(0.51 \%)$ were differentially expressed (70 upregulated and 47 downregulated) between $\mathrm{F}$ and $\mathrm{S}$ mussels, although the number of DEG decreased when $\mathrm{F}$ vs. $\mathrm{S}$ comparisons were performed for each diet.

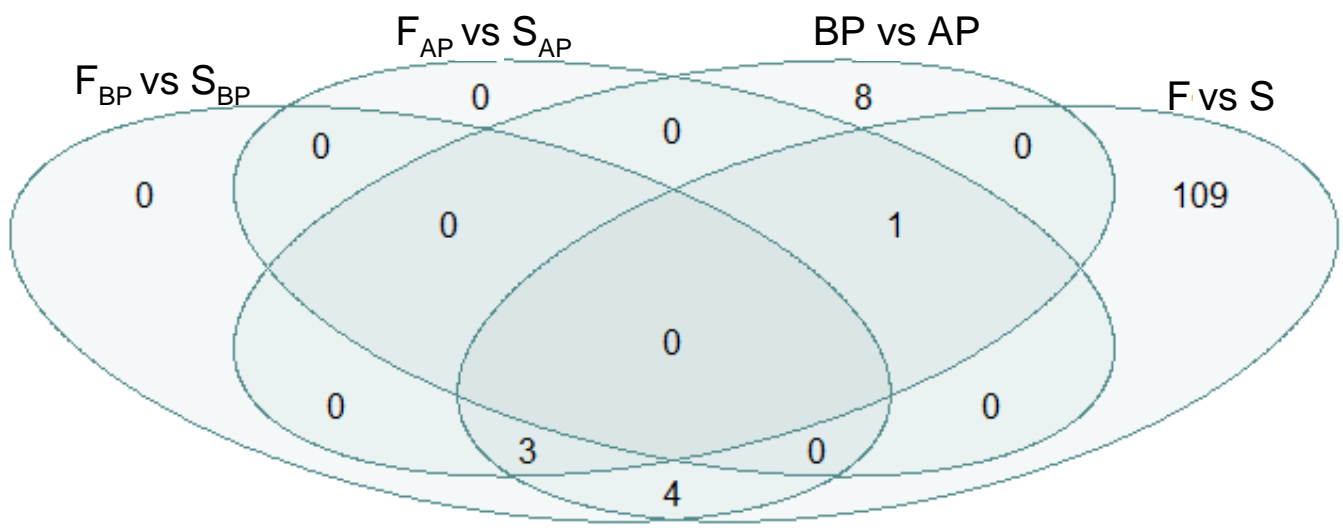

Figure 2. Venn diagram showing the redundancy of the differentially expressed genes between the four selected comparisons of mussels ( $\mathrm{F}_{\mathrm{BP}}$ vs. $\mathrm{S}_{\mathrm{BP}} ; \mathrm{F}_{\mathrm{AP}}$ vs. $\mathrm{S}_{\mathrm{AP}}$; BP vs. AP; F vs. S).

Consequently, we searched for redundancy in DEG among the four comparisons $\left(\mathrm{F}_{\mathrm{BP}}\right.$ vs. $\mathrm{S}_{\mathrm{BP}} ; \mathrm{F}_{\mathrm{AP}}$ vs. $\mathrm{S}_{\mathrm{AP}}$; BP vs. AP and $\mathrm{F}$ vs. $\mathrm{S}$ ) using a Venn diagram (Figure 2). The DEGs of the $1^{\text {st }}$ and $2^{\text {nd }}$ comparison were also found to be differentially expressed in the whole comparison of the F vs S mussels. Conversely, regarding the comparison of the 
maintenance conditions (BP vs. AP), only 4 out of 12 genes were found commonly differentially expressed in F vs. S. No common differentially expressed genes were found for the 4 comparisons.
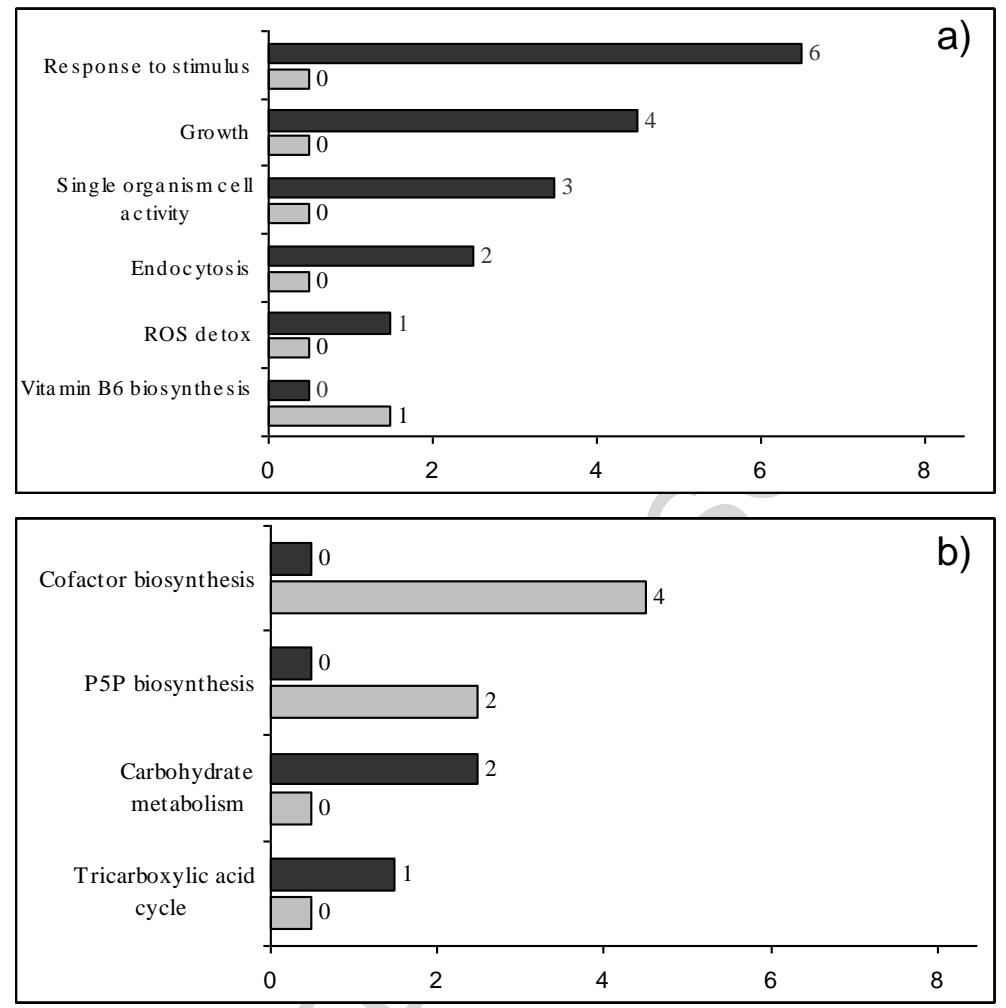

Figure 3. Graphical representation of the upregulated (black) and down-regulated (grey) Biological Process GO terms (a) and KEGG pathway terms (b) in F mussels in comparison with S mussels. The lengths of the bars on the Biological Process graph represent the number of different GO composing each group after REVIGO summarization. KEGG bar length represents the repeat count of the specific pathway.

The resource of the GO term and KEGG pathway association of genes differentially expressed in the comparison between $\mathrm{F}$ and $\mathrm{S}$ mussels ( $\mathrm{F}$ vs. $\mathrm{S}$ ) was intended to achieve a functional interpretation of changes in the transcriptome that are assumed to encode for quantitative differences in growth. A comparison of the functional profiles for the Biological Process and for the KEGG pathways of the selected four comparisons is shown in Figure 3. The main transcriptomic difference between the $\mathrm{F}$ and $\mathrm{S}$ mussels was accounted for by the upregulation of the response to stimulus (37.5\%), growth $(20 \%)$ and cell activity (18.75\%) processes. Regarding the KEGG pathway on $\mathrm{S}$ individuals, cofactor and pyridoxal-5-phosphate biosynthesis 
pathways were found to be upregulated on $\mathrm{S}$ individuals and carbohydrate metabolism, and tricarboxylic acid cycle pathways were found to be upregulated on $\mathrm{F}$ individuals. A list of annotated differentially expressed genes is shown in Table 3. 
Table 3. List of differentially expressed genes in F vs S and BP vs AP comparisons. Gene name, E-value and description were obtained with Annocript by Blastx against Swiss-Prot and UniRef databases. Log FC: Log2-fold change. P: adjusted p value.

\begin{tabular}{|c|c|c|c|c|c|c|}
\hline Comparison & Regulation & Gene name & E-value & Description & $\log$ FC & $\mathbf{P}$ \\
\hline \multirow[t]{22}{*}{ F vs $S$} & \multirow[t]{15}{*}{ Up } & Q05049 / A0A1L8HCH0 & $1.00 \mathrm{E}^{-16} / 2.00 \mathrm{E}^{-15}$ & Integumentary mucin C.1 (Fragment) & 3.97 & 0.042 \\
\hline & & Q80ZA4 / K1Q166 & $0.0 / 0.0$ & Fibrocystin-L & 1.89 & 0.001 \\
\hline & & -/K1Q7V2 & $-/ 3.00 \mathrm{E}^{-10}$ & DENN domain-containing protein 3 & 1.58 & $<0.001$ \\
\hline & & A0MSJ1 / K1PT11 & $7.00 \mathrm{E}-15 / 5.00 \mathrm{E}^{-13}$ & Collagen alpha-1(XXVII) chain B & 1.37 & 0.034 \\
\hline & & Q60754 / UPI00042A 9BFF & $8.00 \mathrm{E}-08 / 4.00 \mathrm{E}^{-10}$ & Macrophage receptor MARCO & 1.33 & 0.044 \\
\hline & & Q9WVT6/K1QCX8 & $4.00 \mathrm{E}-18 / 2.00 \mathrm{E}^{-26}$ & Carbonic anhydrase 14 & 1.30 & 0.003 \\
\hline & & - / S4UD24 & $-/ 8.0 o E^{-09}$ & Nitric oxide synthase & 1.18 & 0.019 \\
\hline & & Q5USW0 / T1WDY6 & $6.00 \mathrm{E}^{-31} / 1.00 \mathrm{E}^{-99}$ & Growth/differentiation factor 8- Myostatin & 1.13 & 0.001 \\
\hline & & P21793/UPI0005C3B0DE & $2.00 \mathrm{E}^{-14} / 9.00 \mathrm{E}^{-91}$ & Decorin & 1.02 & 0.009 \\
\hline & & - / K1P9F1 & $-/ 2.00 \mathrm{E}^{-18}$ & $\begin{array}{l}\text { Insulin-like growth factor-binding protein complex } \\
\text { acid labile chain }\end{array}$ & 0.95 & 0.035 \\
\hline & & P37889 / K1QKY6 & $1.00 \mathrm{E}^{-16} / 2.00 \mathrm{E}^{-32}$ & Fibulin-2 & 0.66 & 0.021 \\
\hline & & Q8WXX0 / K1QK11 & $4.00 \mathrm{E}^{-145} / 0.0$ & Dynein heavy chain 7 axonemal & 0.66 & 0.023 \\
\hline & & Q4R3F0/UPI0005C3C6F2 & $8.00 \mathrm{E}^{-07} / 0.0$ & Protein tilB homolog & 0.60 & 0.022 \\
\hline & & P02469 / UPI00097509DE & $4.00 \mathrm{E}^{-176} / 0.0$ & Laminin subunit beta-1 & 0.59 & 0.038 \\
\hline & & Q4S5X1 / A0A0L8GP61 & $1.00 \mathrm{E}^{-94} / 5.00 \mathrm{E}^{-103}$ & Citrate synthase mitochondrial & 0.56 & 0.007 \\
\hline & \multirow[t]{7}{*}{ Down } & - / A0A0A7AD04 & $-/ 3.00 \mathrm{E}^{-25}$ & CRP-I 9 & -4.39 & 0.021 \\
\hline & & Q922Q8 / J9Q3A8 & $2.00 \mathrm{E}^{-45} / 2.00 \mathrm{E}^{-54}$ & Leucine-rich repeat-containing 59 (Fragment) & -3.38 & 0.016 \\
\hline & & Q16820 / A0A194ALD8 & $1.00 \mathrm{E}^{-17} / 3.00 \mathrm{E}^{-123}$ & Metalloendopeptidase & -3.35 & 0.021 \\
\hline & & - / Q8MW54 & $-/ 8.00 \mathrm{E}^{-24}$ & Precollagen-P & -3.08 & 0.007 \\
\hline & & O34245 / K5UM09 & $1.00 \mathrm{E}^{-57} / 5.00 \mathrm{E}^{-111}$ & Anaerobic C4-dicarboxylate transporter & -2.98 & 0.034 \\
\hline & & P06582 / G3GAE5 & $3.00 \mathrm{E}^{-07} / 5.00 \mathrm{E}^{-172}$ & $\begin{array}{l}\text { Small heat shock protein } 24.1 \\
\text { Putative pyridoxine bios vnthesis SNZERR }\end{array}$ & -2.84 & 0.014 \\
\hline & & Q8WPW2 / H9LHX0 & $7.00 \mathrm{E}^{-81} / 4.00 \mathrm{E}^{-97}$ & (Fragment) & -2.51 & 0.016 \\
\hline
\end{tabular}




\begin{tabular}{|c|c|c|c|c|c|c|}
\hline & & Q86IV5 / K1R157 & $5.00 \mathrm{E}^{-40} / 2.00 \mathrm{E}^{-118}$ & Countin-1 & -1.96 & 0.041 \\
\hline & & Q9R1X5 / K1PW26 & $2.00 \mathrm{E}^{-31} / 2.00 \mathrm{E}^{-82}$ & Multidrug resistance-associated protein 5 & -1.81 & 0.021 \\
\hline & & $\mathrm{P} 56470$ / A0A0C5Q4G0 & $2.00 \mathrm{E}^{-53} / 1.00 \mathrm{E}^{-147}$ & Galectin & -0.94 & 0.035 \\
\hline \multirow[t]{2}{*}{$\mathrm{BP}$ vs AP } & Up & $\begin{array}{l}\text { - / UPI0005C3A5A7 } \\
\text { Q9UBI9 / UPI0005C35386 } \\
\text { O73888 / J7IEQ6 } \\
\end{array}$ & $\begin{array}{r}-/ 4.00 \mathrm{E}^{-15} \\
9.00 \mathrm{E}^{-55} / 1.00 \mathrm{E}^{-110} \\
1.00 \mathrm{E}^{-43} / 2.00 \mathrm{E}^{-147} \\
\end{array}$ & $\begin{array}{l}\text { PREDICTED uncharacterized protein } \\
\text { LOC105332971 } \\
\text { Headcase protein homolog } \\
\text { Glutathione S-transferase sigma } 2\end{array}$ & $\begin{array}{l}1.53 \\
1.74 \\
1.50 \\
\end{array}$ & $\begin{array}{l}0.003 \\
0.030 \\
0.047\end{array}$ \\
\hline & Down & $\begin{array}{l}\text { - / K1QKK4 } \\
\text { Q8C8M1 / K1QAY9 } \\
\text { Q7T3X9 / UPI000947D88F } \\
\text { - / K1R4H5 } \\
\text { P22232 / K1QG65 }\end{array}$ & $\begin{array}{l}-/ 7.00 \mathrm{E}-07 \\
5.00 \mathrm{E}-43 / 1.00 \mathrm{E}-50 \\
2.00 \mathrm{E}-10 / 1.00 \mathrm{E}-08 \\
-/ 6.00 \mathrm{E}-07 \\
1.00 \mathrm{E}-118 / 4.00 \mathrm{E}- \\
123\end{array}$ & $\begin{array}{l}\text { Protocadherin beta-4 } \\
\text { Protein FAM60A } \\
\text { Notch-regulated ankyrin repeat-containing protein B } \\
\text { TNFAIP3-interacting protein } 2 \\
\text { rRNA 2'-O-methyltransferase fibrillarin }\end{array}$ & $\begin{array}{r}-2.15 \\
-1.17 \\
-0.81 \\
-0.67 \\
-0.78\end{array}$ & $\begin{array}{r}<0.001 \\
0.003 \\
0.032 \\
0.033 \\
0.047\end{array}$ \\
\hline
\end{tabular}




\section{Discussion}

In the present study, we analysed the gene expression differences in the gill tissue between fast-growing $(\mathrm{F})$ and slow-growing $(\mathrm{S})$ mussels that were maintained for the long term in the laboratory, while being fed experimental diets of phytoplankton and silt dosed either below (BP) or above (AP) the pseudofaeces threshold. In accordance to what we reported previously from a similar experiment (Prieto et al., 2018), the faster growth of the $\mathrm{F}$ mussels (both $\mathrm{F}_{\mathrm{BP}}$ and $\mathrm{F}_{\mathrm{AP}}$ ) was based on their capacity to display higher clearance rates and higher pre-ingestive selection efficiencies (physiological results will be published elsewhere). Irrespective of the diet fed (BP or AP), increased capacity for water filtration and particle acquisition in $\mathrm{F}$ mussels have been found to be coupled with the possession of significantly higher gill-surface areas, a feature of the fast-growing phenotype that we have also found in our previous studies on mussels (Prieto et al. 2018) and clams (Tamayo et al. 2011).

The experiments of physiological energetics (Prieto et al., in prep) revealed only minor differences in the physiological parameters of mussels fed BP and AP diets. In good agreement with the physiological results, the transcriptomic profiles (HCL results) were very similar between them and only a reduced number of genes were differentially expressed. Three of the annotated DEGs (glutathione S-transferase, headcase protein and protocadherin $\beta$ ) previously have been reported to be upregulated in response to environmental stress and/or bacterial infection in bivalves (Manduzio et al. 2004; Park et al. 2009; Kim et al. 2009; De Zoysa et al. 2011; Li et al. 2018; Rey-Campos et al. 2019). However, any interpretation regarding possible differences in the stimulation of immune response in mussels feed below or above the pseudofaeces level is complicated because BP mussels overexpressed glutathione S-transferase, whereas the other two genes were differentially expressed in AP mussels. The remaining annotated DEGs (Notch-regulated ankyrin repeat-containing protein (NRARP), TNFAIP3-interacting protein 2 and FAM60A protein and rRNA 2'-O-methyltransferase fibrillarin) act in several pathways involved in cell differentiation, proliferation, apoptosis and RNA and protein methylation in bivalves such as notch pathway (Bassim et al. 2014), TFG-beta signalling pathway (Wei et al. 2017) and MAP/ERK pathway. Li et al. (2016) reported that TNFAIP3-interacting protein was downregulated in individuals of Chlamys farreri exposed to Benzopyrene and suggested that the reduction in TNFAIP3 was indicative of depressed metabolic rate and hampered progression of mitosis. In the present 
experiment, overexpression of 4 genes involved in cell proliferation pathways in the mussels that were fed above pseudofaeces level could suggest the existence of an increased gill cell renewal requirement in AP mussels. However, more analysis should be performed to confirm such a hypothesis.

The low impact that nutritional condition and feeding mode (below or above the pseudofaeces threshold) exert on the gill transcriptome contrasts with the broad differences associated with the differences in growth rate between $\mathrm{F}$ and $\mathrm{S}$ specimens: 117 differentially expressed genes in gill tissues. The classification of these genes according to Biological Process GO terms indicated that the differences mainly affect responses to stimulus, growth and cellular activity processes. Thus, the GO term findings supported the higher growth rates and activity levels of $F$ individuals in comparison with $\mathrm{S}$ mussels. Not surprisingly, previous works on interindividual growth rate differences in bivalves have also described similar GO terms as the main processes underlying growth differences; for instance, Wilson et al. (2016) reported that $19 \%$ of GO terms of differentially expressed genes in fast-growing Mya arenaria are associated with cell structure, whereas $17 \%$ refer to signalling and growth, $12 \%$ to energy and nutrient metabolism and $10 \%$ to DNA/RNA and protein synthesis. Regarding the KEGG terms, energetic metabolism terms were referred to $F$ individuals in good correspondence to their higher activity levels. Upregulation of Cofactor and P5P biosynthesis pathway in $\mathrm{S}$ individuals seems to involve differences in protein metabolism that could underlie differences in the protein turnover between growth groups, as described in previous studies (Hawkins et al. 1986, 1996). The P5P biosynthesis pathway could either indicate a higher rate of anaerobic metabolism, which in bivalves is based on the utilization of amino acids via opine dehydrogenases, or aspartate-succinate pathway (Hochachka and Somero. 2002)

Most differentially expressed (DE) genes between the present $\mathrm{F}$ and $\mathrm{S}$ individuals lack a clear association to GO terms because the studied model presents only few sequences annotated in the tools allowing performance of the GO analysis. Thus, emphasis has been placed on the individual (rather than the group) analysis of DE genes and their functions to decipher the transcriptomic basis of growth rate differences. 


\subsection{Upregulated genes in F mussels.}

Upregulation of growth differential factor-8, also known as myostatin, and insulin-like growth factor in the gill of $\mathrm{F}$ mussels would appear meaningfully associated with the higher gill surface area exhibited by fast growers. Myostatin is a negative regulator of muscle growth in vertebrates, and Wang et al. (2010) found that polymorphism of the myostatin gene was correlated with differential growth traits in mammals. In bivalves, myostatin have been suggested to have alternative functions that are related with cell development (Saina and Technau, 2009; Núñez-Acuña and Gallardo-Éscarate, 2014; Morelos et al. 2015; Niu et al. 2015). Insulin-like peptides have been reported to act as growth regulators of soft tissues and shell in bivalves (Taylor et al. 1996; Gricourt et al. 2003), and their roles in determining interindividual growth rate differences in bivalves have been recently suggested by Saavedra et al. (2017), who found a significant overexpression of NOV-like protein in the gills of fastgrowing Ruditapes decussatus. Using the PROSITE tool on the highly differentially expressed genes $(\mathrm{FC}>8, \mathrm{FDR}<0.01)$, we have found that, in addition to myostatin and insulin-like peptides, $\mathrm{F}$ individuals upregulated an epidermal growth factor-like (EGF). Valenzuela-Miranda et al. (2015) also reported the overexpression of EGFs in the muscle of $\mathrm{F}$ specimens in the abalone Haliotis rufescens. EGF is expressed in various tissues of oysters (Sun et al. 2014) and has been suggested to induce cell proliferation and migration during wound healing and to stimulate glycolytic enzymes such as phosphofructokinase and pyruvate kinase (Canesi et al. 2000).

In addition to overexpressing growth-regulators, the gills of $\mathrm{F}$ mussels overexpressed genes involved in the structure and functionality of the extracellular matrix (ECM), such as collagen, laminin, fibulin and decorin. Some of these genes have been previously reported to be differentially expressed between fast- and slow-growing individuals of different invertebrates: For instance, collagen, has been found to be upregulated in F individuals in abalones (Valenzuela-Miranda et al. 2015) and clams (Saavedra et al. 2017). Genomic (Zhang et al. 2012) and transcriptomic (Zhao et al. 2012) analyses have suggested that collagen might play an important role in shell formation and soft tissue growth and repair in bivalves. In addition, collagen also appears to play a relevant role in the adhesion and migration of haemocytes to the ECM (Koutsogiannaki and Kaloyianni, 2011) and likely plays a crucial role in the process of cell immunity during inflammatory response (Adams, 2018). Fibulin have been reported 
to act in association with laminin and collagen in development and biomineralization processes (Timpl et al. 2003; Sleight et al. 2015). Decorin interacts with some growth factors such as EGF, and its binding with myostatin has been described to cause hypertrophy in human muscle cells (Kanzleiter et al. 2014).

The $\mathrm{F}$ mussels in the present experiment were found to overexpress mucin, the backbone glycoprotein that forms the matrix of the mucus (Espinosa et al. 2016). In bivalves, the filtered particles are retained in the mucus strings circulating through the ciliated groves and transported to the labial palps to be either ingested or rejected as pseudofaeces (Beninger and St-Jean, 1997; Urrutia et al. 2001). A higher putative mucus production in $\mathrm{F}$ individuals would be in concordance with their higher clearance rates and higher pre-ingestive selection efficiencies, with both physiological parameters greatly contributing to interindividual differences in the growth rate of mussels (Prieto et al. 2018). Consistent with the higher clearance rates and higher mucin expression, the gills of $\mathrm{F}$ mussels also overexpressed fibrocystin, which is involved in tubulogenesis and ciliary activity (Ward et al. 2003), as well as the dynein and tilB homologue protein genes that are involved in the conversion of ATP hydrolysis into mechanical work (Gibbons and Rowe. 1965; Kavlie et al. 2010; Horani et al. 2013). Dynein overexpression in $\mathrm{F}$ specimens has also been reported in Haliotis rufescens (ValenzuelaMiranda et al., 2015). Overexpression of these genes in F mussels seems to correlate well with the higher filtering activity of the mussels. Recently, Lafont et al. (2019) reported that fibrocystin was one of the upregulated genes in oyster larvae with higher rates of survival to herpes virus (OsHV-1) infection in an experiment that showed transgenerational immune priming in Crassostrea gigas.

Processes involved in the metabolic energy supply and ATP turnover are especially relevant to the growth rate of bivalves, and thus, the finding that 2 genes related to energy metabolism were upregulated in $\mathrm{F}$ individuals is highly meaningful. Previous approaches to the characterization of genetic differences between fast- and slow-growing individuals of different species have emphasized the importance of differential aspects of the energetic metabolism between growth lines. For instance, Meyer and Manahan (2010) found ATP-synthase and two different NADH dehydrogenase subunits upregulated in $\mathrm{F}$ individuals of the oyster $C$. gigas, Wilson et al. (2016) found fatty acid synthase like-1 and fatty acid synthase like-2 genes upregulated in fast-growing individuals of $M$. arenaria, and Saavedra et al. (2017) 
found the NADH subunit upregulated in $\mathrm{F}$ individuals of the clam Ruditapes decussatus. In the present study, we found citrate synthase (CS) and carbonic anhydrase upregulated in the gill of $\mathrm{F}$ individuals. Citrate synthase is a specific marker of aerobic metabolism considered an indicator of the general physiological status of the organism (Garcia-Esquivel et al. 2001, 2002; Pernet et al. 2012; Guévélou et al. 2013) and has been shown to correlate with respiration rates in facultative anaerobes such as intertidal invertebrates (Dahlhoff et al. 2002). Higher citrate synthase expression in our F mussels might thus be indicative of increased energy requirements of gill tissue to sustain higher filtering activity. The carbonic anhydrase enzyme family maintains the $\mathrm{pH} / \mathrm{salinity}$ balance and favours the exchange of respiratory gases (Breton, 2001) and has been reported to play a role in the process of biomineralization in the mantle tissue (Zhang et al. 2012; Hüning et al. 2016). Finally, DENN domain-containing protein 3, also found to be upregulated in $\mathrm{F}$ individuals, is involved in the regulation conversion of inactive GDP-bound to GTP form and vesicle-mediated transport pathways (Marat et al. 2011). We have not found evidence of a DENN domain-containing protein function in bivalves.

The gill of $\mathrm{F}$ individuals upregulated two genes directly related with the immune system, probably located in the haemocytes: nitric oxide synthase (NOS) and the scavenger receptor MARCO (macrophage receptor with collagenous structure). NOS has been detected in haemocytes of several bivalves (Liu et al. 2018) and produces nitric oxide, a pathogen-killing molecule with broad antiviral and antiparasitic effects (Pautz et al. 2010). In mammals, MARCO is a receptor for bacteria expressed mainly in macrophages; in bivalves, it has been previously reported in Mytilus galloprovincialis (Moreira et al. 2015).

\subsection{Upregulated genes in S mussels.}

The gills of the slow-growing mussels overexpress many genes involved in immune, defence and cell stress responses, such as HSP24, leucine-rich repeat proteins, metalloendopeptidase and galectin. The overexpression of heat shock proteins has been commonly found in organisms maintained under temperature stress (Hofman and Somero, 1996; Somero 2012; Lockwood et al. 2013), salinity stress (Zhao et al. 2012) metal exposure (Zhang et al. 2012) and/or bacterial exposure (Genard et al. 2013). In addition, Zhang et al. 2012 found an overexpression of HSP genes in the oyster Crassostrea gigas under various stress conditions (air exposure, thermal stress, salinity 
stress and metal exposure) and concluded that HSP induction could be a common defence against all stresses in $C$. gigas. Leucine-rich repeat proteins have been described to be involved in the immunity of invertebrates (Wang et al. 2016) and metalloendopeptidase, seems to be key component of the response against bacterial infections (Miyoshi and Shinoda, 2000). Galectin is probably associated with haemocytes (Espinosa et al. 2016; Vasta et al. 2015) and participates in the recognition of glycans of the surface of virus and bacteria (Nikapitiya et al. 2014). In good correspondence with the present study, Saavedra et al. (2017) also found differences between fast- and slow-growing individuals of the clam Ruditapes decussatus in the immune and defence processes of digestive gland and gills. $\mathrm{S}$ individuals overexpressed genes involved in immune and defence processes such as defensin and tumour necrosis factor member 11, whereas $\mathrm{F}$ individuals were found to overexpress different genes, such as sialic acid-binding lectin and hydramacin-1. They conclude that the observed high differences in the expression of immune and defence genes could reflect a differential fitness among individuals, promoting faster growth rates in those individuals able to fight more efficiently against diseases. In the present study, most of the overexpressed genes in $\mathrm{S}$ mussels were found to belong to the immune and defence system and cellular stress, which strongly suggests a greater prevalence of pathogens/diseases or a higher susceptibility to the pathogens. As suggested by Genard et al. (2013), when analysing the physiological response of $C$. gigas larvae submitted to bacterial infection, extra investments in supporting defence mechanisms might drain energy resources from normal processes in healthy organisms, resulting in reduced feeding and growth performances.

In addition, the strong upregulation of countin- $1 \quad(\mathrm{FC} \approx 4)$, a cell-counting factor that limits the maximum size of the multicellular structure by the downregulation of the cell adhesion mediator gp24, seems to indicate developmental process inhibition in $\mathrm{S}$ individuals. Symptoms of impairment in the respiratory function of the gill affecting aerobic ATP production are also evident in S mussels: Evidence of increased use of anaerobic metabolic pathways includes strong upregulation of anaerobic C4dicarboxylate transporter $(\mathrm{FC} \approx 8)$, as well as the increased biosynthesis of pyridoxal-5 -phosphate. Similarly, Saavedra et al. (2017) have reported upregulation in the digestive gland of $\mathrm{S}$ clams of enzymes very likely involved in anaerobic metabolism (e.g., malate dehydrogenase and glycerol-3-phosphate dehydrogenase). 


\subsection{Conclusions and prospects}

The present results show the existence of substantial differences in the transcriptome of the gills of $\mathrm{F}$ and $\mathrm{S}$ individuals. The gills of the fast-growing mussels overexpressed growth factors and genes that are involved in the maintenance of relevant cellular functions, such as the maintenance of the ciliary activity, the development of a robust extracellular matrix contributing to antibacterial defence and the maintenance of aerobic metabolic pathways. This transcriptomic profile in the $\mathrm{F}$ mussels suggests that the gills are well equipped to maintain higher filtering activities that enable fastgrowing mussels to maximize food acquisition and sustain fast growth rates. In contrast, slow-growing mussels overexpress genes involved in the immune system and genes that participate in cellular-stress responses and anaerobic metabolic pathways. These results could suggest that $\mathrm{S}$ individuals would have a greater prevalence of pathogens/diseases or a higher susceptibility to the pathogens. Further analysis with different organs (e.g., digestive gland) are needed to obtain a holistic view of the transcriptomic basis of fastgrowth in bivalves; however, the present study suggests that the immune response might be a crucial component of the interindividual differences in growth rate in Mytilus galloprovincialis mussel spats.

\section{Acknowledgements}

This study was funded through the project AGL2013-49144-C3-1-R of the Spanish Ministry of Economy and Competitiveness. D. Prieto was funded by an FPI grant from the Basque Government. The authors are thankful for the technical and human support provided by SGIker of UPV/EHU (European funding: ERDF and ESF). Finally, D. Prieto especially wants to thank Dr. A. Huvet for all the help provided.

\section{References}

Adams, J. C. (2018). Matricellular Proteins: Functional Insights From Non-mammalian Animal Models. In Current topics in developmental biology (Vol. 130, pp. 39-105). Academic Press.

Astorga, M. P. (2014). Genetic considerations for mollusk production in aquaculture: current state of knowledge. Frontiers in genetics, 5,435.

Bassim, S., Tanguy, A., Genard, B., Moraga, D., \& Tremblay, R. (2014). Identification of Mytilus edulis genetic regulators during early development. Gene, 551(1), 65-78. 
Bassim, S., Chapman, R. W., Tanguy, A., Moraga, D., \& Tremblay, R. (2015). Predicting growth and mortality of bivalve larvae using gene expression and supervised machine learning. Comparative Biochemistry and Physiology Part D: Genomics and Proteomics, 16, 59-72.

Bayne, B. L., Svensson, S., \& Nell, J. A. (1999)a. The physiological basis for faster growth in the Sydney rock oyster, Saccostrea commercialis. The Biological Bulletin, 197(3), 377-387.

Bayne, B. L., Hedgecock, D., McGoldrick, D., \& Rees, R. (1999)b. Feeding behaviour and metabolic efficiency contribute to growth heterosis in Pacific oysters [Crassostrea gigas (Thunberg)]. Journal of experimental marine biology and ecology, 233(1), 115-130.

Beninger, P. G., \& St-Jean, S. D. (1997). The role of mucus in particle processing by suspension-feeding marine bivalves: unifying principles. Marine Biology, 129(2), 389-397.

Breton, S. (2001). The cellular physiology of carbonic anhydrases. Jop, 2(4 Suppl), 159-164.

Brown, J. R. (1988). Multivariate analyses of the role of environmental factors in seasonal and site-related growth variation in the Pacific oyster Crassostrea gigas. Marine Ecology Progress Series, 225236.

Canesi, L., Ciacci, C., Betti, M., \& Gallo, G. (2000). Growth factor-mediated signal transduction and redox balance in isolated digestive gland cells from Mytilus galloprovincialis Lam. Comparative Biochemistry and Physiology Part C: Pharmacology, Toxicology and Endocrinology, 125(3), 355-363.

Cheng, C., \& Pounds, S. (2007). False discovery rate paradigms for statistical analyses of microarray gene expression data. Bioinformation, 1(10), 436.

Dahlhoff, E. P., Stillman, J. H. and Menge, B. A. (2002). Physiological community ecology: variation in metabolic activity of ecologically important rocky intertidal invertebrates along environmental gradients. Integrative and Comparative Biology,. 42, 862-71.

De la Peña, T. C., Cárcamo, C. B., Díaz, M. I., Brokordt, K. B., \& Winkler, F. M. (2016). Molecular characterization of two ferritins of the scallop Argopecten purpuratus and gene expressions in association with early development, immune response and growth rate. Comparative Biochemistry and Physiology Part B: Biochemistry and Molecular Biology, 198, 46-56.

De Zoysa, M., Nikapitiya, C., Oh, C., Lee, Y., Whang, I., Lee, J. S., Choi, C.Y., \& Lee, J. (2011). Microarray analysis of gene expression in disk abalone Haliotis discus discus after bacterial challenge. Fish \& shellfish immunology, 30(2), 661-673.

Devos, A., Dallas, L. J., Voiseux, C., Lecomte-Pradines, C., Jha, A. N., \& Fiévet, B. (2015). Assessment of growth, genotoxic responses and expression of stress related genes in the Pacific oyster Crassostrea gigas following chronic exposure to ionizing radiation. Marine pollution bulletin, 95(2), 688-698. 
Dickie, L. M., Boudreau, P. R., \& Freeman, K. R. (1984). Influences of stock and site on growth and mortality in the blue mussel (Mytilus edulis). Canadian Journal of Fisheries and Aquatic Sciences, 41(1), 134-140

Espinosa, E. P., Koller, A., \& Allam, B. (2016). Proteomic characterization of mucosal secretions in the eastern oyster, Crassostrea virginica. Journal of proteomics, 132, 63-76.

Fernández-Reiriz, M. J., Irisarri, J., \& Labarta, U. (2016). Flexibility of Physiological Traits Underlying Inter-Individual Growth Differences in Intertidal and Subtidal Mussels Mytilus galloprovincialis. PLoS One, 11(2), e0148245.

García-Esquivel, Z., Bricelj, V. M., \& González-Gómez, M. A. (2001). Physiological basis for energy demands and early postlarval mortality in the Pacific oyster, Crassostrea gigas. Journal of Experimental Marine Biology and Ecology, 263(1), 77-103.

García-Esquivel, Z., Bricelj, V. M., \& Felbeck, H. (2002). Metabolic depression and whole-body response to enforced starvation by Crassostrea gigas postlarvae. Comparative Biochemistry and Physiology Part A: Molecular \& Integrative Physiology, 133(1), 63-77.

Genard, B., Miner, P., Nicolas, J. L., Moraga, D., Boudry, P., Pernet, F., \& Tremblay, R. (2013). Integrative study of physiological changes associated with bacterial infection in Pacific oyster larvae. PLoS One, 8(5), e64534.

Gibbons, I. R., \& Rowe, A. J. (1965). Dynein: a protein with adenosine triphosphatase activity from cilia. Science, 149(3682), 424-426.

Gracey, A. Y., Chaney, M. L., Boomhower, J. P., Tyburczy, W. R., Connor, K., \& Somero, G. N. (2008). Rhythms of gene expression in a fluctuating intertidal environment. Current Biology, 18(19), 1501-1507.

Gricourt, L., Bonnec, G., Boujard, D., Mathieu, M., \& Kellner, K. (2003). Insulin-like system and growth regulation in the Pacific oyster Crassostrea gigas: hrIGF-1 effect on protein synthesis of mantle edge cells and expression of an homologous insulin receptor-related receptor. General and comparative endocrinology, 134(1), 44-56.

Guévélou, E., Huvet, A., Sussarellu, R., Milan, M., Guo, X., Li, L., ... \& Boudry, P. (2013). Regulation of a truncated is oform of AMP-activated protein kinase $\alpha(\mathrm{AMPK} \alpha)$ in response to hypoxia in the muscle of Pacific oyster Crassostrea gigas. Journal of Comparative Physiology B, 183(5), 597611.

Hawkins, A. J. S., Bayne, B. L., \& Day, A. J. (1986). Protein turnover, physiological energetics and heterozygosity in the blue mussel, Mytilus edulis: the basis of variable age-specific growth. Proceedings of the Royal Society of London B: Biological Sciences, 229(1255), 161-176.

Hawkins, A. J. S., Smith, R. F. M., Bayne, B. L., \& Heral, M. (1996). Novel observations underlying the fast growth of suspension-feeding shellfish in turbid environments: Mytilus edulis. Marine Ecology Progress Series, 179-190. 
Hochachka, P. W., \& Somero, G. N. (2002). Biochemical adaptation: mechanism and process in physiological evolution. New York: Oxford University Press.

Hofmann, G. E., \& Somero, G. N. (1996). Interspecific variation in thermal denaturation of proteins in the congeneric mussels Mytilus trossulus and M. galloprovincialis: evidence from the heat-shock response and protein ubiquitination. Marine Biology, 126(1), 65-75.

Horani, A., Ferkol, T. W., Shoseyov, D., Wasserman, M. G., Oren, Y. S., Kerem, B., ... \& Elpeleg, O. (2013). LRRC6 mutation causes primary ciliary dyskinesia with dynein arm defects. PLoS One, $8(3)$, e59436.

Hüning, A. K., Lange, S. M., Ramesh, K., Jacob, D. E., Jackson, D. J., Panknin, U., ... \& Melzner, F. (2016). A shell regeneration assay to identify biomineralization candidate genes in mytilid mussels. Marine genomics, 27, 57-67.

Kanehisa M. 2002. The KEGG database. In: Novartis Foundation Symposium, 247:91-101

Kanzleiter, T; Rath, M; Görgens, SW; Jensen, J; Tangen, DS; Kolnes, AJ; Kolnes, KJ; Lee, S; Eckel, J; Schürmann, A; Eckardt, K (2014). "The myokine decorin is regulated by contraction and involved in muscle hypertrophy". Biochem Biophys Res Commun. 450: 1089-1094..

Kavlie, R. G., Kernan, M. J., \& Eberl, D. F. (2010). Hearing in Drosophila requires TilB, a conserved protein associated with ciliary motility. Genetics, 185(1), 177-188.

Kim, M., Ahn, I. Y., Cheon, J., \& Park, H. (2009). Molecular cloning and thermal stress -induced expression of a pi-class glutathione S-transferase (GST) in the Antarctic bivalve Laternula elliptica. Comparative Biochemistry and Physiology Part A: Molecular \& Integrative Physiology, 152(2), 207-213.

Koehn, R. K., \& Shumway, S. E. (1982). Genetic/physiological explanation for differential growth rate among individuals of the American oyster, Crassostrea virginica (Gmelin). Marine Biology Letters, 2(3), 35-42.

Koutsogiannaki, S., \& Kaloyianni, M. (2011). Effect of $17 \beta$-estradiol on adhesion of Mytilus galloprovincialis hemocytes to selected substrates. Role of alpha2 integrin subunit. Fish \& shellfish immunology, 31(1), 73-80.

Lafont, M., Goncalves, P., Guo, X., Montagnani, C., Raftos, D., \& Green, T. (2019). Transgenerational plasticity and antiviral immunity in the Pacific oyster (Crassostrea gigas) against Ostreid herpesvirus 1 (OsHV-1). Developmental \& Comparative Immunology, 91, 17-25.

Leitao, A., Boudry, P., \& Thiriot-Quievreux, C. (2001). Negative correlation between aneuploidy and growth in the Pacific oyster, Crassostrea gigas: ten years of evidence. Aquaculture, 193(1), 3948.

Li, Z., Cha, Y., Hu, B., Wen, C., Jian, S., Yi, P., \& Gang, Y. (2018). Identification and characterization of two distinct sigma-class glutathione-S-transferase from freshwater bivalve Cristaria plicata. 
Comparative Biochemistry and Physiology Part B: Biochemistry and Molecular Biology, 219, $52-61$.

Liu, Z., Li, M., Yi, Q., Wang, L., \& Song, L. (2018). The Neuroendocrine-Immune Regulation in Response to Environmental Stress in Marine Bivalves. Frontiers in Physiology, 9.

Lockwood, B. L., Sanders, J. G., \& Somero, G. N. (2010). Transcriptomic responses to heat stress in invasive and native blue mussels (genus Mytilus): molecular correlates of invasive success. Journal of Experimental Biology, 213(20), 3548-3558.

Mallet, A. L., \& Haley, L. E. (1983). Growth rate and survival in pure population matings and crosses of the oyster Crassostrea virginica. Canadian Journal of Fisheries and Aquatic Sciences, 40(7), 948-954.

Manduzio, H., Monsinjon, T., Galap, C., Leboulenger, F., \& Rocher, B. (2004). Seasonal variations in antioxidant defences in blue mussels Mytilus edulis collected from a polluted area: major contributions in gills of an inducible is oform of $\mathrm{Cu} / \mathrm{Zn}$-superoxide dismutase and of glutathione S-transferase. Aquatic Toxicology, 70(1), 83-93.

Marat, A. L., Dokainish, H., \& McPherson, P. S. (2011). DENN domain proteins: regulators of Rab GTPases. Journal of Biological Chemistry, 286(16), 13791-13800.

Meyer, E., \& Manahan, D. T. (2010). Gene expression profiling of genetically determined growth variation in bivalve larvae (Crassostrea gigas). Journal of Experimental Biology, 213(5), 749758.

Miyoshi, S. I., \& Shinoda, S. (2000). Microbial metalloproteases and pathogenesis. Microbes and infection, 2(1), 91-98.

Moreira, R., Pereiro, P., Canchaya, C., Posada, D., Figueras, A., \& Novoa, B. (2015). RNA-Seq in Mytilus galloprovincialis: comparative transcriptomics and expression profiles among different tissues. BMC genomics, 16(1), 728.

Morelos, R. M., Ramírez, J. L., García - Gasca, A., \& Ibarra, A. M. (2015). Expression of the myostatin gene in the adductor muscle of the Pacific lion - paw scallop Nodipecten subnodosus in association with growth and environmental conditions. Journal of Experimental Zoology Part A: Ecological Genetics and Physiology, 323(4), 239-255.

Nikapitiya, C., McDowell, I. C., Villamil, L., Muñoz, P., Sohn, S., \& Gomez-Chiarri, M. (2014). Identification of potential general markers of disease resistance in American oysters, Crassostrea virginica through gene expression studies. Fish \& shellfish immunology, 41(1), 2736.

Niu, D., Wang, L., Bai, Z., Xie, S., Zhao, H., \& Li, J. (2015). Identification and expression characterization of the myostatin (MSTN) gene and association analys is with growth traits in the razor clam Sinonovacula constricta. Gene, 555(2), 297-304. 
Núñez-Acuña, G., \& Gallardo-Escárate, C. (2014). The myostatin gene of Mytilus chilensis evidences a high level of polymorphism and ubiquitous transcript expression. Gene, 536(1), 207-212.

Pace, D. A., Marsh, A. G., Leong, P. K., Green, A. J., Hedgecock, D., \& Manahan, D. T. (2006). Physiological bases of genetically determined variation in growth of marine invertebrate larvae: a study of growth heterosis in the bivalve Crassostrea gigas. Journal of Experimental Marine Biology and Ecology, 335(2), 188-209.

Park, H., Ahn, I. Y., Kim, H., Lee, J., \& Shin, S. C. (2009). Glutathione S-transferase as a biomarker in the Antarctic bivalve Laternula elliptica after exposure to the polychlorinated biphenyl mixture Aroclor 1254. Comparative Biochemistry and Physiology Part C: Toxicology \& Pharmacology, $150(4), 528-536$.

Pautz, A., Art, J., Hahn, S., Nowag, S., Voss, C., \& Kleinert, H. (2010). Regulation of the expression of inducible nitric oxide synthase. Nitric oxide, 23(2), 75-93.

Pernet, F., Barret, J., Le Gall, P., Corporeau, C., Degremont, L., Lagarde, F., ... \& Keck, N. (2012). Mass mortalities of Pacific oysters Crassostrea gigas reflect infectious diseases and vary with farming practices in the Mediterranean Thau lagoon, France. Aquaculture Environment Interactions, 2(3), 215-237.

Prieto, D., Urrutxurtu, I., Navarro, E., Urrutia, M. B., \& Ibarrola, I. (2018). Mytilus galloprovincialis fast growing phenotypes under different restrictive feeding conditions: Fast feeders and energy savers. Marine Environmental Research,140, 114-125.

Rey-Campos, M., Moreira, R., Valenzuela-Muñoz, V., Gallardo-Escárate, C., Novoa, B., \& Figueras, A. (2019). High individual variability in the transcriptomic response of Mediterranean mussels to Vibrio reveals the involvement of myticins in tissue injury. Scientific reports, 9(1), 3569.

Ritchie, ME, Phipson, B, Wu, D, Hu, Y, Law, CW, Shi, W, and Smyth, GK (2015). limma powers differential expression analyses for RNA-sequencing and microarray studies. Nucleic Acids Research 43(7), e47.

Saavedra, C., \& Bachère, E. (2006). Bivalve genomics. Aquaculture, 256(1), 1-14.

Saavedra, C., Milan, M., Leite, R. B., Cordero, D., Patarnello, T., Cancela, L., \& Bargelloni, L. (2017). A microarray study of carpet-shell clam (Ruditapes decussatus) shows common and organ-specific growth-related gene expression differences in gills and digestive gland. Frontiers in Physiology, $8,943$.

Saina, M., \& Technau, U. (2009). Characterization of myostatin/gdf8/11 in the starlet sea anemone Nematostella vectensis. Journal of Experimental Zoology Part B: Molecular and Developmental Evolution, 312(7), 780-788.

Sighn, S. M., \& Zouros, E. (1978). Genetic variation associated with growth rate in the American oyster (Crassostrea virginica). Evolution, 32(2), 342-353. 
Sigrist, C. J., Cerutti, L., De Castro, E., Langendijk-Genevaux, P. S., Bulliard, V., Bairoch, A., \& Hulo, N. (2009). PROSITE, a protein domain database for functional characterization and annotation. Nucleic acids research,38(suppl_1), D161-D166.

Sleight, V. A., Thorne, M. A., Peck, L. S., \& Clark, M. S. (2015). Transcriptomic response to shell damage in the Antarctic clam, Laternula elliptica: Time scales and spatial localisation. Marine genomics, 20, 45-55.

Smyth, G. K., Ritchie, M., Thorne, N., Wettenhall, J., Shi, W., \& Hu, Y. (2002). limma: Linear Models for Microarray and RNA-Seq Data User's Guide.

Somero, G. N. (2012). The physiology of global change: linking patterns to mechanisms. Annual Review of Marine Science, 4, 39-61

Suarez-Ulloa, V., Fernandez-Tajes, J., Aguiar-Pulido, V., Prego-Faraldo, M. V., Florez-Barros, F., SextoIglesias, A., Mendez, J. \& Eirin-Lopez, J. M. (2015). Unbiased high-throughput characterization of mussel transcriptomic responses to sublethal concentrations of the biotoxin okadaic acid. PeerJ, 3, e1429.

Sun, L., Huan, P., Wang, H., Liu, F., \& Liu, B. (2014). An EGFR gene of the Pacific oyster Crassostrea gigas functions in wound healing and promotes cell proliferation. Molecular biology reports, 41(5), 2757-2765.

Sussarellu, R., Fabioux, C., Le Moullac, G., Fleury, E., \& Moraga, D. (2010). Transcriptomic response of the Pacific oyster Crassostrea gigas to hypoxia. Marine genomics, 3(3), 133-143.

Supek, F., Bošnjak, M., Škunca, N., \& Šmuc, T. (2011). REVIGO summarizes and visualizes long lists of gene ontology terms. PloS One, 6(7), e21800.

Tamayo, D., Ibarrola, I., Urrutia, M. B., \& Navarro, E. (2011). The physiological basis for interindividual growth variability in the spat of clams (Ruditapes philippinarum). Aquaculture, $321(1), 113-120$.

Tamayo, D., Ibarrola, I., Urrutxurtu, I., \& Navarro, E. (2014). Physiological basis of extreme growth rate differences in the spat of oyster (Crassostrea gigas). Marine biology, 161(7), 1627-1637.

Tanguy, A., Bierne, N., Saavedra, C., Pina, B., Bachère, E., Kube, M., ... \& Boutet, I. (2008). Increasing genomic information in bivalves through new EST collections in four species: development of new genetic markers for environmental studies and genome evolution. Gene, 408(1), 27-36.

Taylor, B. E., Donovan, D. A., Mclean, E., Donaldson, E. M., \& Carefoot, T. H. (1996). Effect of recombinant vertebrate growth hormones on growth of adult abalone, Haliotis kamtschatkana. Aquaculture, 140(1-2), 153-158.

Teixeira De Sousa, J., Matias, D., Joaquim, S., Ben-Hamadou, R., \& Leitão, A. (2011). Growth variation in bivalves: New insights into growth, physiology and somatic aneuploidy in the carpet shell Ruditapes decussatus. Journal of experimental marine biology and ecology, 406(1), 46-53. 
Timpl, R., Sasaki, T., Kostka, G., \& Mon-Li, C. (2003). Fibulins: a versatile family of extracellular matrix proteins. Nature reviews. Molecular cell biology, 4(6), 479.

Toro, J. E., \& Vergara, A. M. (1998). Growth and Heterozygosity in a 12 - Month - Old Cohort of Ostrea chilensis Obtained by Mass Spawning in the Laboratory. Marine Ecology, 19(4), 311323.

Urrutia, M. B., Navarro, E., Ibarrola, I., \& Iglesias, J. I. P. (2001). Preingestive selection processes in the cockle Cerastoderma edule: mucus production related to rejection of pseudofaeces. Marine Ecology Progress Series, 209, 177-187.

Valenzuela-Miranda, D., Del Río-Portilla, M. A., \& Gallardo-Escárate, C. (2015). Characterization of the growth-related transcriptome in California red abalone (Haliotis rufescens) through RNA-Seq analysis. Marine genomics, 24, 199-202

Vasta, G. R., Feng, C., Bianchet, M. A., Bachvaroff, T. R., \& Tasumi, S. (2015). Structural, functional, and evolutionary aspects of galectins in aquatic mollusks: from a sweet tooth to the Trojan horse. Fish \& shellfish immunology, 46(1), 94-106.

Wang, X., Meng, X., Song, B., Qiu, X., \& Liu, H. (2010). SNPs in the myostatin gene of the mollusk Chlamys farreri: as sociation with growth traits. Comparative Biochemistry and Physiology Part B: Biochemistry and Molecular Biology, 155(3), 327-330.

Wang, M., Wang, L., Xin, L., Wang, X., Wang, L., Xu, J., ... \& Song, L. (2016). Two novel LRR-only proteins in Chlamys farreri: Similar in structure, yet different in expression profile and pattern recognition. Developmental \& Comparative Immunology, 59, 99-109.

Ward, C. J., Yuan, D., Masyuk, T. V., Wang, X., Punyashthiti, R., Whelan, S., ... \& Harris, P. C. (2003). Cellular and subcellular localization of the ARPKD protein; fibrocystin is expressed on primary cilia. Human molecular genetics, 12(20), 2703-2710.

Wei, J., Fan, S., Liu, B., Zhang, B., Su, J., \& Yu, D. (2017). Transcriptome analysis of the immune reaction of the pearl oyster Pinctada fucata to xenograft from Pinctada maxima. Fish \& shellfish immunology, 67, 331-345.

Wilson, J. J., Grendler, J., Dunlap-Smith, A., Beal, B. F., \& Page, S. T. (2016). Analysis of Gene Expression in an Inbred Line of Soft-Shell Clams (Mya arenaria) Displaying Growth Heterosis: Regulation of Structural Genes and the NOD2 Pathway. International journal of genomics, 2016, 10 pages.

Xu, Y. F., Liang, X., Chen, Y. R., Li, Y. F., \& Yang, J. L. (2016). Wnt7b gene expression and functional analys is in the mussel Mytilus coruscus. Genetics and molecular research: GMR, 15(4).

Zhang, G., Fang, X., Guo, X., Li, L., Luo, R., Xu, F., ... \& Xiong, Z. (2012). The oyster genome reveals stress adaptation and complexity of shell formation. Nature, 490(7418), 49.

Zhao, X., Yu, H., Kong, L., \& Li, Q. (2012). Transcriptomic responses to salinity stress in the Pacific oyster Crassostrea gigas. PLoS ONE, 7(9), e46244. 


\section{Appendices}

Table A.1. Expression of housekeeping genes: mean values ( \pm SD) of the experimental mussel groups.

\begin{tabular}{lrrrr} 
& \multicolumn{1}{c}{$\mathrm{F}_{\mathrm{BP}}$} & \multicolumn{1}{c}{$\mathrm{S}_{\mathrm{BP}}$} & \multicolumn{1}{c}{$\mathrm{F}_{\mathrm{AP}}$} & \multicolumn{1}{c}{$\mathrm{S}_{\mathrm{AP}}$} \\
\hline Elongation factor 1-alpha & $15.64 \pm 0.08$ & $15.61 \pm 0.09$ & $15.66 \pm 0.09$ & $15.68 \pm 0.14$ \\
Tubulin alpha-1 chain & $14.92 \pm 0.12$ & $14.92 \pm 0.12$ & $14.80 \pm 0.06$ & $14.87 \pm 0.20$ \\
Ribosomal protein S15 (Fragment) & $15.23 \pm 0.11$ & $15.11 \pm 0.08$ & $15.12 \pm 0.14$ & $15.17 \pm 0.12$ \\
40S ribosomal protein S4 (Fragment) & $16.59 \pm 0.08$ & $16.50 \pm 0.12$ & $16.59 \pm 0.06$ & $16.54 \pm 0.09$ \\
Collagen protein (Fragment) & $6.64 \pm 0.11$ & $6.61 \pm 0.27$ & $6.41 \pm 0.02$ & $6.40 \pm 0.12$ \\
- & $6.41 \pm 0.38$ & $6.22 \pm 0.10$ & $6.23 \pm 0.10$ & $6.11 \pm 0.09$ \\
Actin adductor muscle & $16.88 \pm 0.16$ & $16.90 \pm 0.08$ & $16.85 \pm 0.12$ & $16.90 \pm 0.18$ \\
60S acidic ribosomal protein P0 & $16.76 \pm 0.12$ & $16.69 \pm 0.08$ & $16.73 \pm 0.06$ & $16.76 \pm 0.04$ \\
- & $6.25 \pm 0.10$ & $6.24 \pm 0.05$ & $6.38 \pm 0.15$ & $6.28 \pm 0.04$ \\
- & $11.72 \pm 0.05$ & $11.65 \pm 0.06$ & $11.71 \pm 0.11$ & $11.56 \pm 0.05$ \\
Precollagen-NG & $9.16 \pm 0.39$ & $7.99 \pm 0.36$ & $9.47 \pm 0.55$ & $8.02 \pm 0.18$ \\
E3 ubiquitin-protein ligase UBR2 & $9.74 \pm 0.07$ & $9.62 \pm 0.10$ & $9.74 \pm 0.09$ & $9.58 \pm 0.11$ \\
Ubiquitin carboxyl-terminal hydrolase isozyme L5 & $9.27 \pm 0.15$ & $9.19 \pm 0.16$ & $9.26 \pm 0.20$ & $9.32 \pm 0.13$ \\
Ubiquitin carboxyl-terminal hydrolase 40 & $7.50 \pm 0.14$ & $7.41 \pm 0.12$ & $7.54 \pm 0.08$ & $7.46 \pm 0.14$ \\
E3 ubiquitin-protein ligase RNF8 & $7.51 \pm 0.08$ & $7.54 \pm 0.11$ & $7.54 \pm 0.19$ & $7.39 \pm 0.09$ \\
Ubiquitin-conjugating enzyme E2 L3 & $9.30 \pm 0.20$ & $9.53 \pm 0.03$ & $9.46 \pm 0.13$ & $9.49 \pm 0.08$ \\
Uncharacterised protein & $6.22 \pm 0.04$ & $6.39 \pm 0.33$ & $6.28 \pm 0.23$ & $6.30 \pm 0.19$ \\
PREDICTED CTTNBP2 N-terminal-like protein & & & & \\
partial & $7.64 \pm 0.06$ & $7.59 \pm 0.07$ & $7.62 \pm 0.01$ & $7.54 \pm 0.06$ \\
Collagen type IV alpha-3-binding protein & $10.87 \pm 0.10$ & $10.78 \pm 0.06$ & $10.66 \pm 0.09$ & $10.74 \pm 0.08$ \\
E3 ubiquitin-protein ligase TRIM71 & $7.51 \pm 0.22$ & $7.33 \pm 0.11$ & $7.48 \pm 0.13$ & $7.37 \pm 0.12$ \\
\hline
\end{tabular}




\section{Highlights}

1- Fast- and slow-growing mussel (Mytilus galloprovincialis) spat were found to differentially express 117 genes in gill tissue.

2- Fast-growing mussels overexpressed genes involved in response to stimulus,growth and cell activity processes.

3- Slow-growing mussels overexpressed genes involved in immune and defence processes.

4- Feeding above or below the pseudofaeces production threshold did not exert a relevant effect on the gill transcriptome. 